\title{
Peta Batimetri Danau Rawapening
}

\author{
Tri Retnaningsih Soeprobowati \\ Jurusan Biologi FMIPA Universitas Diponegoro \\ Jalan Prof Soedarto SH, Tembalang Semarang \\ trsoeprobowati@yahoo.co.id
}

\begin{abstract}
Abstrak
Lake has an important function as source of water; maintain biodiversity; source of protein; manage toxicity; device to reduce river flooding; source of groundwater; device climate; transportation and touris; medium; and for cultural and religion activities. Semi natural lake of Rawapening has function for hydroelectricity power, irrigation for agriculture, fisheries, and tourism. For maintaning those functions, lake batimetric map is required for limnological study as well as for basic informasi for development lake management. However, there is no batimetric map of Rawapening Lake after1976 lake's sketch by Goltenboth. Therefore, this survey was conducted in order to update batimetric map of Rawapening. On August $16^{\text {th }}, 2008$, echosounding was donecfross section and lake edge every 30 second. Recorded data on the GPS then interpolated to the lake depth form in every dot of echosounding.The deepest part of Rawapening Lake was 18 metres, around Bukit Cinta spring. Comparing to Goltenboth sketch, the Rawapening Lake depth was not quite change. North West part of the lake remain has 2-4.7 metres depth. However, based on sedimentation rate, the shallowness lake was very sharply, and predicted that in 2021 Rawapening Lake will full of sediment. Maintaning lake depth is a must to maintain lake's function.
\end{abstract}

Key words: batimetri, Danau Rawapening, limnologi

\section{PENDAHULUAN}

Danau merupakan cekungan pada permukaan bumi yang berisi air sehingga merupakan ekosistem perairan tawar yang tergenang (lentik), yang lebih besar dibandingkan dengan kolam. Menurut Moss et al. (1996), badan air yang berukuran lebih dari 2 ha merupakan danau, termasuk di dalamnya waduk dan gravel pits(Williams, et al., 2003). Namun, Dwoning et al. (2006) menetapkan ukuran danau minimal 0,1 ha.

Danau merupakanbadan air yang sangat penting, sebagai bagian dari ekosistem penyangga yang menopang kehidupan. Danau adalahsumber air, penopang fungsi biodiversitas, sumber dan tempat pembentukan protein, pengendali toksisitas di badan air, peredam fluktuasi banjir di sungai, sumber yang mengisi air tanah, pengendali iklim, sarana transportasi dan olah raga dan wisata, serta yang tidak kalah penting adalah posisinya yang sentral dalam tradisi, budaya, dan religi (Hehanusa \& Haryani, 2009).

Berdasarkan stratifikasi thermal, maka secara vertikal danau dapat dibagi menjadi 3 lapisan, yaitu:
1. epilimnion, merupakan lapisan bagian atas perairan, temperatur relatif konstan dan hangat, seluruh air dapat tercampur dengan baik oleh angin maupun gelombang;

2. metalimnion, merupakan lapisan di bawah epilimnion dan di atas hipolimnion dengan perubahan temperatur relatif besar antara epilimnion dan hipolimnion, sehingga disebut juga sebagai termoklin;

3. hipolimnion, merupakanlapisanbawahdanau, temperaturlebihdingin, densitas air lebihbesar (Effendi, 2003).

Berdasarkanproses pembentukan-nya, maka danau dibedakan menjadi2 yaitu danau alami dan danau buatan (waduk). Antara danau dan waduk berbeda dalam hal:daerah aliran, bentuk, kedalaman, gradient kedalaman, erosi garis pantai, perkembangan garis pantai, muatan sedimen, deposisi sedimen, turbiditas, fluktuasi muka air, inflow, outflow, dan laju penggelontoran (Wetzel, 2001).

Kedalaman bawah air dan studi tiga dimensi danau dikenal sebagai batimetri. Peta batimetri menunjukkan relief dasar atau dataran danau dengan garis-garis kontur kedalaman, sehingga 
memberikan informasi tambahan untuk navigasi permukaan. Data batimetri diperoleh dengan teknik interpolasi untuk pendugaan kedalaman. Teknik interpolasi yang sering digunakan adalah teori universal Kriging (Larson, 2002).

Keunggulanteknik Kriging antara lain dapat menghubungkan titik-titik bernilai ekstrim tanpa mengisolasinya, lebih akurat karena memadukan korelasi spasial antar data dan mampu mengkuantifikasi variansi nilai yang diestimasi (Largueche, 2006), dan mengadaptasi parameter untuk memprediksi perubahan nilai masukan (Siregar dan Selamat, 2009). Namun teknikKriging memiliki kelemahan berdasarkan asumsi bahwa data menyebar normal, sementara kebanyakan data lapangan tidak demikian; estimasi variogram sulit diperoleh bila titik yang digunakan tidak mencukupi (Siregar dan Selamat, 2009).

Secara alami, Danau Rawapening terbentuk melalui proses letusan vulkanik yang mengalirkan lava basalt dan menyumbat aliran Kali Pening di daerah Tuntang. Sebagai akibatnya lembah Kali Pening menjadi terendam air dan kemudian menjadi reservoir alami yang keberadaannya sangat penting bagi sistem ekologi (Wardani,2002). Rawapening berubah menjadi danau semi alami sejak pembangunan pertama dam dikembangkan di hulu Sungai Tuntang, pada tahun 1912 - 1916, sehingga permukaan air rawa naik dengan memanfaatkan Sungai Tuntang sebagai satu-satunya pintu keluar. Penggenangan lembah Kali Pening tersebut membawa dampak besar terhadap perubahan ekosistemnya, seperti penggambutan sisa-sisa hutan tropik, invasi tumbuhan air, terbentuknya pulau terapung dan berkembangnya komunitas akuatik. Perluasan danau dilakukan pada tahun 1936, sehingga genangan air maksimum mencapai \pm 2.667 hektar pada musim penghujan dan $\pm 1,650$ hektar pada musim kemarau (Goltenboth \& Timotius, 1994).

Danau Rawapening memiliki kapasitas tampung air maksimum 65 juta $\mathrm{m}^{3}$ pada elevasi muka air 463,9 m dan kapasitas air minimum 25 juta $\mathrm{m}^{3}$ pada elevasi muka air $462,05 \mathrm{~m}$. Pada tahun 1998, volume air danau Rawapening sebanyak $45.930 .578 \mathrm{~m}^{3}$ dengan luas genangan antara 1.650 sampai 2.770 ha. Curah hujan ratarata pada daerah tangkapan $1.437 \mathrm{~mm} /$ tahun dengan total inflow pada musim penghujan sebesar 18.190 liter/detik dan pada musim kemarau 3.848 liter/detik dari 9 Sub-sub DAS (Pemerintah Kabupaten Semarang, 2000). Kondisi tersebut di atas menyebabkan air di danau mengalami penambahan terus menerus, sementara air yang keluar hanya melalui 1 outlet yaitu Sungai Tuntang: melalui penguapan, rembesan, pemanfaatan lahan pasang surut dan area genangan air menjadi daerah pertanian, dan bertambahnya pulau terapung, sehingga volume air danau fluktuatif. Penambahan air juga membawa material-material dari daerah hulu yang kemudian diendapkan di danau, sehingga memberi sumbangan endapan yang cukup besar. Seiring perjalanan waktu, maka ada kecenderungan perubahan tipe danau menjadi tipe "piring" karena proses pendangkalan yang terjadi .

Danau Rawapening memiliki fungsi utama untuk menahan laju aliran air permukaan, menampungnya, yang kemudian dimanfaatkan untuk PLTA, irigasi pertanian, pengendali banjir daerah hilir, pariwisata, perikanan darat, penyedia air baku dan air untuk industri, persawahan pasang surut, handicraft, dan penambangan gambut untuk pupuk organik dan sarana budidaya jamur (KLH, 2011).

Berdasarkan klasifikasi Oldeman, Danau Rawapening termasuk zone $\mathrm{C}$, dan zone $\mathrm{D}$, dan berdasarkan klasifikasi iklim Koppen beriklim Af sehingga klasifikasi iklimnya memiliki ciri sebagai iklim tropis dengan curah hujan yang tinggi. Suhu rata-rata antara $25^{\circ} \mathrm{C}-29^{\circ} \mathrm{C}$ serta kelembaban udara antara 70-90\%. Mengacu kepada curah hujan, maka dapat diketahui bahwa pada musim penghujan terjadi debit banjir dan pada musim kemarau terjadi defisit hingga mengalami kekeringan. Dalam 5 tahun terakhir, telah terjadi perubahan iklim, mengakibatkan semakin menurunnya banyak hari hujan dan curah hujan dan setiap daerah memiliki variasi yang tinggi, sehingga mengakibatkan pada musim kering, air danau semakin berkurang dan sebaliknya pada musim penghujan air danau berlebihan sehingga menimbulkan banjir(KLH, 2011).Penelitian ini bertujuan untuk menyajikan peta batimetri Danau Rawapening sebagai landasan penelitian limnologi dan pengembangan pengelolaaannya agar fungsinya tetap optimal. 


\section{METODE PENELITIAN}

Metode akustik digunakan untuk pembuatan peta batimetri Danau Rawapening. Pada prinsipnya metode akustik berdasarkan perambatan suara, sehingga ada sistem akustik aktif dan sistem akustik pasif. Guna penentuan batimetri danau digunakan sistem akustik aktif, berupa sinyal akustik yang diemisikan dan direfleksikan oleh dasar danau. Waktu yang diperlukan untuk pergerakan gelombang akustik secara vertikal ke dasar danau dan kembali ke permukaan merupakan data yang diolah untuk menentukan kedalaman danau.

Peta batimetri Danau Rawapening disusun berdasarkan hasil Echosounding yang dilakukan pada tanggal 16 Agustus 2008. GPS dihubungkandenganaccu dan echo-sounder. Petunjuk datum GPS diatursebagai WGS 84 dan sistem koordinatsebagai UTM.

Dilakukanpenyisiranbadan air sebagaicross section dan penyisiran bibir pantai danau.Penelusuran inti danau hanya dapat dilakukan pada lokasi dengan komunitas eceng gondok tidak terlalu padat, sehingga perahu masih mampu menerabasnya.

Pada umumnya di lokasi yang penuh dengan eceng gondok, kedalaman perairan hanya sekitar 1-2 meter. Rute penelusuran hanya dapat dilakukan pada separoh inti danau, karena pada bagian timur laut sampai dengan tenggara kepadatan eceng gondok sangat tinggi dan relatif permanen, sehingga tidak dapat ditembus perahu.

Echo-sounding dilakukan setiap 30 detik selama penelusuran Danau Rawapening berlangsung.Pada tahap ini proses pemetaan sudah berjalan dan data yang didapat adalah posisi titiktitik dan elevasibawah air.

Pengunduhan data lapangandari GPS dengan program Mapsourcedan mengubah formatnya agar kompatibel dengan program Arcview 3.3. Selanjutnya dilakukan pembuatan kontur kedalaman danau berbasis prinsip interpolasi.Pemberian warna kontur gradual menunjukkan perubahan kedalaman.Warna paling gelap merupakan daerah yang paling dalam.

\section{HASIL DAN PEMBAHASAN}

Berdasarkan hasil pemetaan batimetri yang telah dilakukan, maka dijumpai 4 lokasi dengan kedalaman relatif berbeda dengan area yang cukup luas, dan 6 lokasi dengan area yang kecil(Gambar 1). Pada saat dilakukan pemetaan, tinggi muka air philscale Tuntang $168 \mathrm{~cm}$, rerata elevasi danau $477,43 \pm 3,15$ mdpal.

Analisis dari peta batimetri Danau Rawapening menunjukkan kedalaman maksimum 18,4 meter yang terletak di dekat sumber mata air (tuk) Bukit Cinta (warna biru tua), sedangkan kedalaman kurang dari 0,5 meter banyak dijumpai di bagian timur laut - tenggara yang penuh dengan eceng gondok dan cenerung permanen. Semakin tua warna dalam peta batimetri menunjukkan kedalaman danau yang semakin dalam. Jika dibandingkan dengan sketsa batimetri yang dibuat pada tahun 1976 (Goltenboth, 1979, Gambar 2), maka kedalaman Danau Rawapening tidak banyak mengalami perubahan. Sisi Barat laut danau yang semula memiliki kedalaman lebih besar dari 4 meter, pada tahun 2008 masih memiliki kedalaman 2-4,7 meter. Namun Goltenboth (1979) tidak menyampaikan data kedalaman, hanya kisaran kedalaman. Data kedalaman dalam sketsa batimetri > 4 meter, terlalu bias untuk diinterpretasikan, sehingga tingkat perubahan kedalaman danau tidak dapat diketahui.

Kedalaman Danau Rawapening pada penelitian yang dilakukan Goltenboth pada tahun 1976 diketahui bahwa titik terdalam pada waktu musim hujan adalah 11 meter yang terletak di daerah utara (Gambar 2, Golthenboth, 1979). Eksploitasi gambut yang sangat besar mungkin telah merubah lapisan tersebut (Goltenboth \& Timotius, 1994). Pada tahun 2008ketikadilakukanechosounding (Gambar 1) bagian utara tersebut memiliki kedalaman 4 meter, sedangkan bagian terdalam dijumpai di sekitar tuk Bukit Cinta dengan kedalaman 18 meter. Berdasarkan perbandingan tersebut, maka kedalaman Danau Rawapening sejak tahun 1976 tidak banyak mengalami perubahan.Namun, berdasarkanlajusedimentasi, 
Maka diprediksipendangkalan danau terjadi sangat cepat, tahun 2021 Danau Rawapening diprediksi akan menjadi daratan (Pemerintah Kabupaten Semarang, 2000). Berdasarkan prediksi tersebut, volume Danau Rawapening pada tahun 2008 adalah $29.360 .945 \mathrm{~m}^{3}$ dengan rerata kedalaman 1,06. Namun berdasarkan pengukuran batimetri Danau Rawapening yang dilakukan pada 16 Agustus 2008, rerata kedalaman 3,87 $\pm 4,03$ dan volume danau 16.082.908,447 $\mathrm{m}^{3}$. Terdapat perbedaan volume danau yang cukup besar antara prediksi pengurangan volume dan data riil yang diperoleh dari pengukuran batimetri danau.

Prediksi penurunan volume Danau Rawa pening yang dilakukan semata-mata berdasarkan laju sedimentasi dan erosi. Pemanfataan air untuk irigasi dan PLTA tidak dipertimbangkan dalam melakukan prediksi. PLTA Jelok dan Timo dapat beroperasi apabila debit minimum danau $3,5 \mathrm{~m} / \mathrm{det}$, pada elevasi minimal 460,5 mdpal. Pada kondisi tersebut kemampuan maksimum PLTA Jelok menghasilkan 15,500 KW dan Timo 10,500 KW.Lahan pertanian yang dialiri air Danau Rawapening 39,277 Ha (BalitBang Prov Jateng, 2003). Berdasarkan fakta tersebut, maka dalam penghitungan prediksi pengurangan volume danau seharusnya mempertimbangkan faktor pemanfaatan air danau.

\section{KESIMPULAN}

Berdasarkan analisis peta batimetri Danau Rawapening, maka kedalaman maksimal 18,4 meter. 


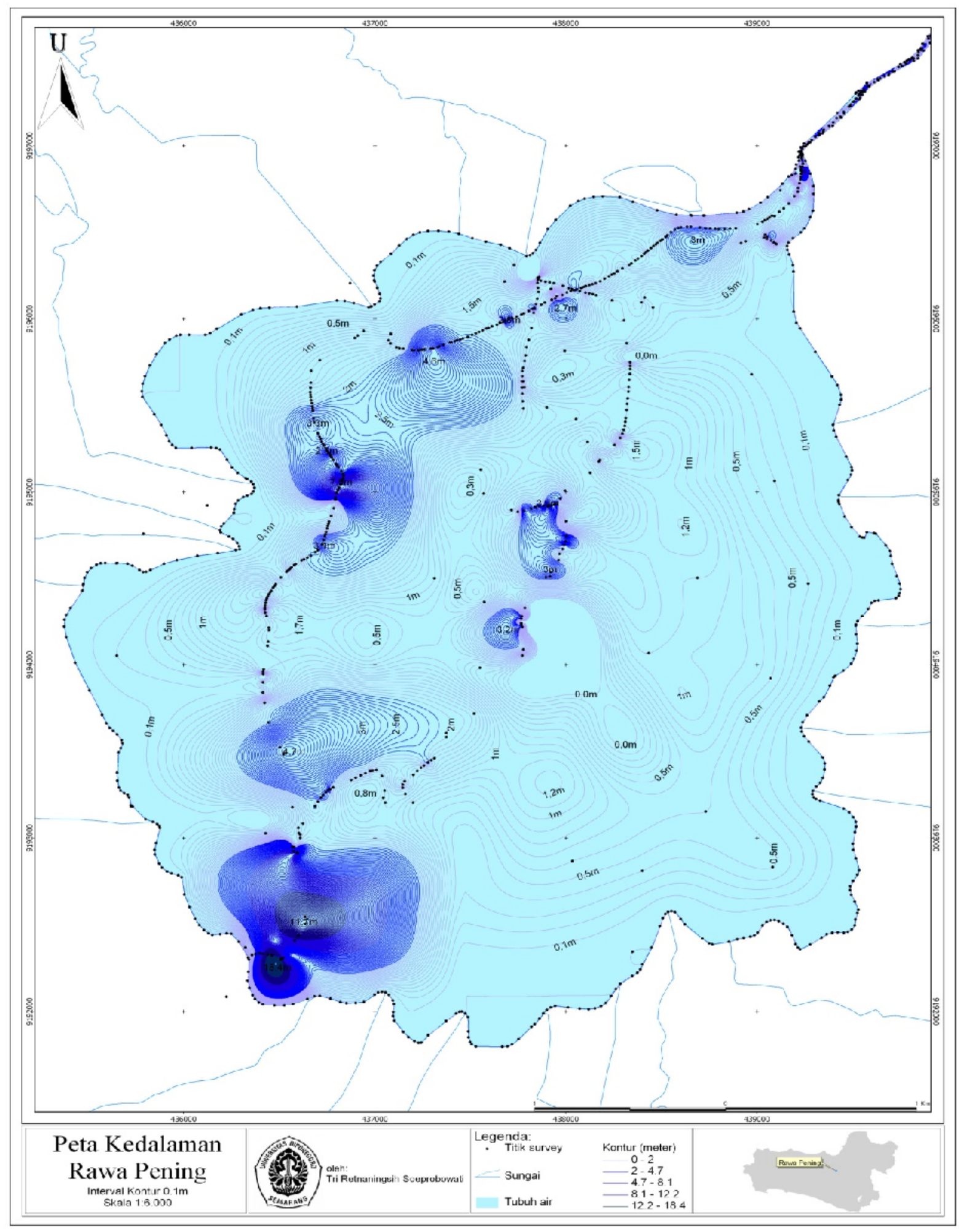

Gambar 1. Petabatimetritahun 2008. Warna semakin tua menunjukkan kedalaman yang lebih besar. 


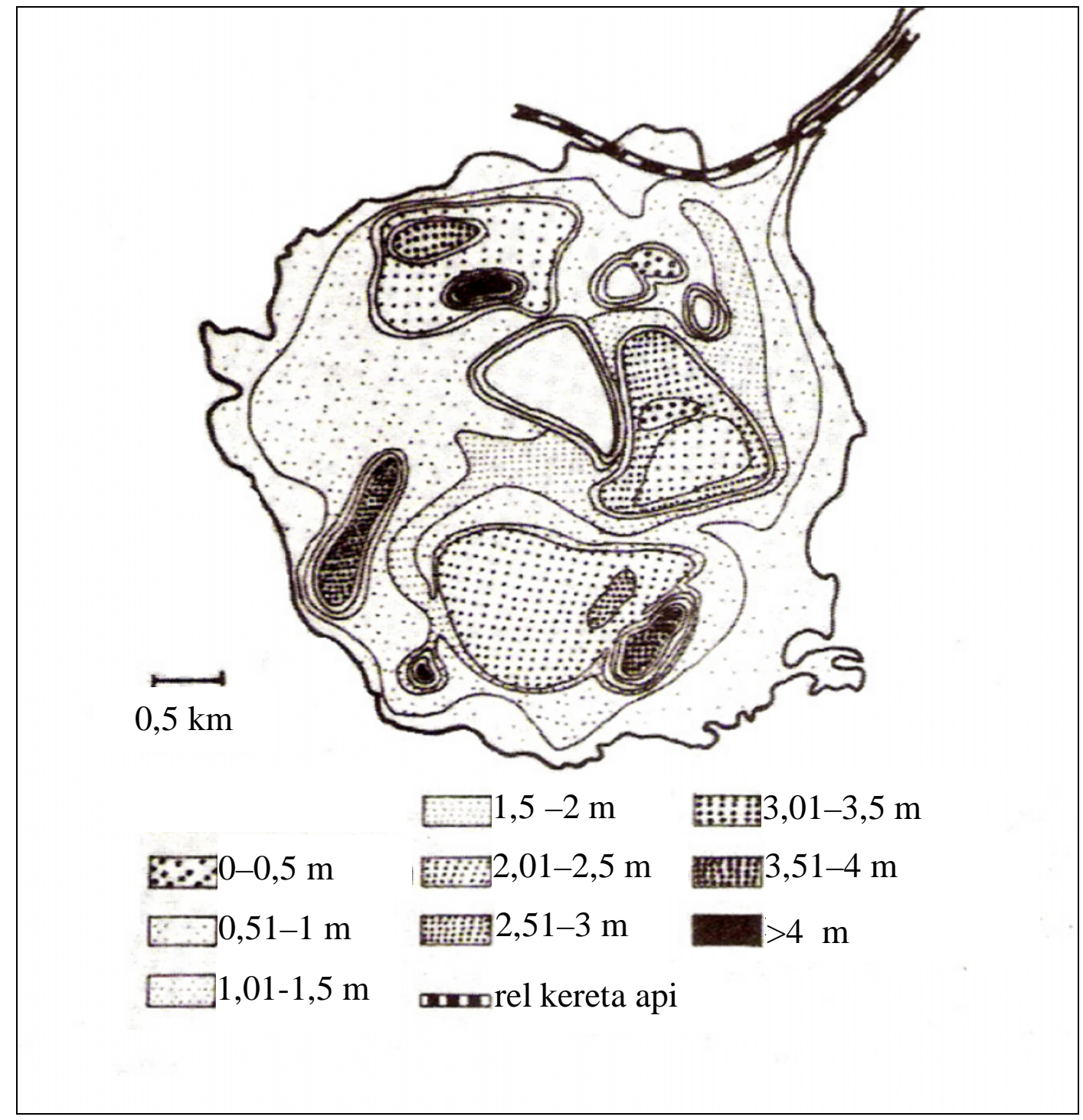

Gambar 2. Sketsapeta batimetrik Danau Rawapening tahun 1976 (Goltenboth, 1979)

\section{DAFTAR PUSTAKA}

BalitBang Prov Jateng, 2003. Penelitian karakteristik Rowopening

Downing J.A., Prairie Y.T., Cole J.J., Duarte C.M., Tranvick L.J., Striegel R.G., McDowell W.H., Kortelainen P., Melack J.M., Middleburg J.J. 2006. The global abundance and size distribution of lakes, ponds and impoundments.Limnology and Oceanography, 51: 2388-2397.

Effendi, H. 2003. Telaah Kualitas Air bagi Pengelola Sumber Daya dan Lingkungan Perairan. Kanisius, Yogyakarta.

Goltenboth, F. 1979. Preliminary final report.The Rawapening Project.Satya Wacana Christian University, Salatiga.
Goltenboth, F. and K.H. Timotius. 1994. Danau Rawapening di Jawa Tengah, Indonesia. Satya Wacana University Press, Salatiga.

Hehanusa, P.E. dan Haryani, G.S. 2009.Klasifikasi morfogenesis danau di Indonesia untuk mitigasi dampak perubahan iklim.Makalah disampaikan dalamKonferensiNasional Danau Indonesia I, Sanur-Denpasar-Bali, 13-15 Agustus 2009.

KLH (Kementerian Lingkungan Hidup). 2011. Profil 15 danau Prioritas Nasional 2010 - 2014.kelemterian Lingkungan Hidup. Jakarta.

Largueche, F.Z.B. 2006. Estimating Soil Contamination with Kriging Interpolation Method. American 
Journal of Applied Science 3(6): 1894-1898

Larson, T.M.J. (2002) Kriging Water Levels with a Regional-Linear and Point Logarithmic Drift, Ground Water33 (1): 338-35

Moss, B.; Johnes, P.; Philips, G. 1996.The Monitoring Of Ecological Quality And The Classification Of Standing Waters In Temperate Regions: A Review And Proposal Based On A Worked Scheme For British Waters Biological Reviews 71(2): , 301-339. Cambridge Philosophical Society

Pemerintah Kabupaten Semarang. 2000. Proyek Perencanaan Tata Lingkungan Daerah Aliran Sungai (DAS) Rawapening. PT. Comarindo Mahameru, Semarang.

Siregar, V.P. dan M.B. Selamat. 2009. Interpolasi dalam pembuatan peta batimetri. E-Journal Ilmu dan Teknologi Kelautan Tropis 1(1): 39-47
Wardani, N.S. 2002. Sisitem Geologi Rawapening. Paper dalam Simposium dan Lokakarya Pelestarian DanauRawapening untuk Pemberdayaan Masyarakat. 18-19 April 2002. Pusat Studi Rawapening, Universitas Kristen Satya Waca, Salatiga

Wetzel, R.G. 2001. Limnology, Lake and River Ecosystems. $3^{\text {rd }}$ ed. Academic Press, NY.

William, P.; Whitfield, M.; Biggs, J.; Bray, S.; Fox, G.; Nicolet, P.; and Sear, D. 2003.Comparative biodiversity of rivers, streams, ditches and ponds in an agricultural landscape in Southern England.Biological Conservation 115: 329-341.

\section{UCAPAN TERIMAKASIH}

Terima kasih diucapkan kepada Arif Sudihatmono Fakultas Geografi UGM, Hari Wibowo dan Nina Desianti yang telah membantu dalam kegiatan echosounding. 
Tri Retnaningsih Soeprobowati 
BIOMA, Desember 2012

ISSN: 1410-8801

Vol. 14, No. 2, Hal. 78-84 